\title{
Alpha 1 antitrypsin distribution in an allergic asthmatic population sensitized to house dust mites
}

\author{
I. Suárez-Lorenzo ${ }^{1 *} \mathbb{D}$, F. Rodríguez de Castro ${ }^{2}$, D. Cruz-Niesvaara ${ }^{3}$, E. Herrera-Ramos ${ }^{4}$, C. Rodríguez-Gallego ${ }^{4}$ \\ and T. Carrillo-Diaz ${ }^{5}$
}

\begin{abstract}
Background and objective: Severe alpha1 antitrypsin deficiency has been clearly associated with pulmonary emphysema, but its relationship with bronchial asthma remains controversial. Some deficient alpha 1 antitrypsin (AAT) genotypes seem to be associated with asthma development. The objective of this study was to analyze the distribution of AAT genotypes in asthmatic patients allergic to house dust mites (HDM), and to asses a possible association between these genotypes and severe asthma.

Methods: A cross-sectional cohort study of 648 patients with HDM allergic asthma was carried out. Demographic, clinical and analytical variables were collected. PI*S and PI*Z AAT deficient alleles of the SERPINA1 gene were assayed by real-time PCR.

Results: Asthma was intermittent in 253 patients and persistent in 395 patients (246 mild, 101 moderate and 48 severe). One hundred and forty-five asthmatic patients (22.4\%) with at least one mutated allele (S or Z) were identified. No association between the different genotypes and asthma severity was found. No significant differences in all clinical and functional tests, as well as nasal eosinophils, IgA and IgE serum levels were observed. Peripheral eosinophils were significantly lower in patients with the $\mathrm{PI}^{*} \mathrm{MS}$ genotype $(p=0.0228)$. Neither association between deficient AAT genotypes or serum ATT deficiency (AATD) and development of severe asthma, or correlation between ATT levels and FEV1 was observed.

Conclusion: In conclusion, the distribution of AAT genotypes in HDM allergic asthmatic patients did not differ from those found in Spanish population. Neither severe ATTD or deficient AAT genotypes appear to confer different clinical expression of asthma.
\end{abstract}

Keywords: Alpha 1 antitrypsin, Alpha 1 antitrypsin deficiency, House dust mites, Asthma, Allergy

\section{Background}

Alpha-1 antitrypsin (AAT) is a serine proteinase inhibitor (PI) that protects alveoli against the destructive effects of neutrophil elastase, proteinase 3 and cathepsin G, which cause destruction of pulmonary parenchyma $[1,2]$. Alpha-1 antitrypsin deficiency (AATD) is an autosomal codominant genetic condition first described by Laurell

\footnotetext{
*Correspondence: isadora.suarez101@alu.ulpgc.es

1 Postgraduate and Doctoral School, Universidad de Las Palmas de Gran Canaria, Camino Real de San Roque, 1, 35015 Las Palmas de Gran Canaria, Las Palmas, Spain

Full list of author information is available at the end of the article
}

and Erikson in 1963 [3]. Multiple genetic variants in the gene encoding AAT, SERPINA1, are associated with low serum AAT levels. The most common deficient alleles are protease inhibitor $\mathrm{PI}^{*} \mathrm{~S}$ and $\mathrm{PI}{ }^{*} \mathrm{Z}$, being $\mathrm{PI}^{*} \mathrm{M}$ the normal variant. $\mathrm{Pi}^{*} \mathrm{ZZ}$ individuals have severe AAT deficiency, with only $10 \%$ of normal serum levels as compared to $\mathrm{Pi}^{*} \mathrm{MM}$ subjects. Individuals homozygous for the $\mathrm{Pi}^{*} \mathrm{~S}$ (Pi*SS) alleles have approximately $60 \%$ of normal serum ATT levels $[4,5]$. Although AATD was initially thought of as a rare disease, it has proven to be underdiagnosed in many countries $[5,6]$. The distribution of deficient alleles depends on the location; for example, $\mathrm{Z}$ variant is more 
prevalent in North and Western Europe, while $S$ variant has a higher prevalence in the South of Europe, particularly in Spain [7]. Nowadays, different national registries provide the exact prevalence of AATD. However, it is still not considered sufficiently by physicians in the diagnostic phase $[8,9]$.

Worldwide, AATD has been frequently related to chronic obstructive pulmonary disease (COPD), premature emphysema and liver failure [10-13], but its relationship with asthma remains controversial [14]. AATD is associated with wheezing and dyspnea, which are also characteristic symptoms of asthma. That is why it is sometimes difficult to differentiate between these conditions [14-16] and, according to the American Thoracic Society (ATS)/European Respiratory Society (ERS) and the World Health organization (WHO), diagnosis of asthma is one of the clinical indications for genetic AATD testing $[17,18]$.

The aim of this study is to analyze the distribution of the most common ATT genotypes in a cohort of asthmatic patients sensitized to house dust mites (HDM). Furthermore, this study attempts to investigate the influence of ATTD and the presence of certain genotypes on the severity of allergic asthma.

\section{Methods}

A cross-sectional cohort study of HDM-sensitive asthmatic patients (skin prick test and specific immunoglobulin E) was carried out. Asthmatic subjects were recruited through the Allergy Clinic of the "Hospital Universitario de Gran Canaria Doctor Negrín" (Canary Islands). All of them were Caucasian, aged over 12 . They all had a diagnosis of asthma, with or without rhinitis or other allergic conditions, and complained of typical asthma symptoms such as wheezing, dyspnea and/or other symptoms which they had suffered from over the previous two years. Patients were divided into four groups (intermittent and persistent mild, moderate and severe), according to the severity of their disease and following the Spanish asthma guideline-GEMA4.0 [19]. Written informed consent was obtained from all subjects before participating in the study, which was approved by the Ethics Committee of the hospital.

Asthma was diagnosed on the basis of a history of asthma symptoms and clinical examination (dyspnea, chest tightness, wheezing, cough), and a significant reversibility of their forced expiratory volume in one second (FEV1), as measured with a spirometer (Flowscreen, Viasys, Germany) upon treatment with bronchodilators, at least in one visit during the patient follow-up [19]. Fractional exhaled nitric oxide (FeNO) was also performed (NIOX-MINO ${ }^{\circledR}$ Aerocrine).
Skin-prick tests were performed with several dust mite allergens (Dermatophagoides pteronyssinus, Dermatophagoides farinae, Blomia tropicalis, Acarus siro, Lepidoglyphus destructor and Tyrophagus putrescientae) from ALK Abelló, Spain. A positive skin-prick test was defined as a mean wheal diameter of at least $3 \mathrm{~mm}$ or larger than that of the negative control following current guidelines [20].

In all subjects, blood eosinophils and neutrophils, and total serum immunoglobulin A (IgA), immunoglobulin E (IgE) and specific IgE to D. pteronyssinus, D. farinae, B. tropicalis, A. siro, L. destructor and T. putrescientae (ImmunoCap, Phadia, Sweden) were determined. ATT serum levels were measured by nephelometry (BNII, Siemens, Erlangen, Germany).

ATT genotypes were determined by using real-time polymerase chain reaction (PCR) and LigthCycler 2.0 for the detection of the mutation according to the technique previously described [21].

Statistical analysis was performed using the nonparametric Kruskal-Wallis test for quantitative variables and Chi square or Fisher tests for qualitative variables. Binary logistic regression was used to determine the association between genotypes and the presence or absence of severe persistent asthma, adjusting for age, smoking habit, significant comorbidity, previous treatment received and some analytical values. The possible correlation between the serum levels of ATT and bronchial functional test parameters was evaluated by Spearman's rank correlation coefficient. A value of $p<0.05$ was considered to be statistically significant. All analyses were performed using the R Project (Version 1.0.153) [22].

\section{Results}

During a period of 22 months, 648 asthmatic patients over 12 years (median age 29 years) who were allergic to HDM were recruited into the study. Four hundred and twenty-five $(66 \%)$ were females and $54(8 \%)$ were smokers. Demographic and clinical characteristics of the patients are listed in Table 1.

According to the GEMA4.0, 253 asthmatic patients were classified as intermittent and 395 as persistent (246 mild, 101 moderate, and 48 severe). Patients with severe asthma were significantly older $\left(\mathrm{p}=1.72^{-12}\right)$ as has been previously reported [23]. In addition, a slightly higher percentage of ex-smokers were seen in the group with severe asthma $(p=0.0301)$, which was considered in the posterior multivariate analysis. Regarding the clinical comorbidity, there was a significantly higher proportion of patients with conjunctivitis in the intermittent asthma group $(p=0.008201)$ and polyposis in the moderate group ( $\mathrm{p}=0.00013$ ), while no significance was observed in terms of rhinitis, chronic sinusitis, atopic dermatitis, 
Table 1 Demographic, clinical and analytical features of the studied population

\begin{tabular}{|c|c|c|c|c|c|c|}
\hline & Global $(n=648)$ & Intermittent $(n=253)$ & Mild $(n=246)$ & Moderate $(n=101)$ & Severe $(n=48)$ & P value* \\
\hline \multicolumn{6}{|l|}{ Sex, n (\%) } & 0.316 \\
\hline Male & $233(34)$ & $90(36)$ & $84(34)$ & $38(38)$ & $11(23)$ & \\
\hline Female & $425(66)$ & $163(64)$ & $162(66)$ & $62(62)$ & $37(77)$ & \\
\hline \multicolumn{6}{|l|}{ Age, years } & $1.72 \mathrm{e}-12^{\ddagger}$ \\
\hline Median $\left(\mathrm{IQ}_{25-75}\right)$ & $29(20-38)$ & $27(20-36)$ & $27(19-35)$ & $34(24-44)$ & $41(34-53)$ & \\
\hline Smoker n (\%) & $54(8)$ & $24(9.5)$ & $21(8.5)$ & $9(9)$ & 0 & 0.369 \\
\hline Obesity n (\%) & $115(18)$ & $46(18.2)$ & $36(14.9)$ & $19(19.2)$ & $13(27)$ & 0.221 \\
\hline Conjunctivitis n (\%) & $107(16.5)$ & $54(21.3)$ & $40(16.3)$ & $11(11)$ & $2(4.2)$ & $0.008201^{\ddagger}$ \\
\hline Rhinitis n (\%) & 640 (98.8) & $250(98.8)$ & $244(99.2)$ & $99(99)$ & $47(97.9)$ & 0.885 \\
\hline Polyposis n (\%) & $17(2.62)$ & $1(0.8)$ & $2(0.8)$ & $9(9)$ & $4(8.3)$ & $0.00013^{\ddagger}$ \\
\hline Chronic sinusitis n (\%) & $32(4.94)$ & $11(4.3)$ & $11(4.5)$ & $8(8)$ & $2(4.2)$ & 0.519 \\
\hline Atopic dermatitis n (\%) & $23(3.55)$ & $12(4.7)$ & $5(2)$ & $5(5)$ & $1(2.1)$ & 0.295 \\
\hline Previous pneumonia n (\%) & $5(0.77)$ & $1(0.4)$ & $2(0.8)$ & $1(1)$ & $1(2.1)$ & 0.332 \\
\hline \multicolumn{6}{|l|}{ FEV1 (I) } & $3.98 \mathrm{e}-22^{\ddagger}$ \\
\hline Median $\left(\mathrm{IQ}_{25-75}\right)$ & $2.9(2.5-3.4)$ & $3.1(2.7-3.6)$ & $2.9(2.6-3.5)$ & $2.6(2.2-3.1)$ & $2.0(1.7-2.5)$ & \\
\hline \multicolumn{6}{|l|}{ FEV1 (\%) } & $1.14 \mathrm{e}-24^{\ddagger}$ \\
\hline Median $\left(\mathrm{IQ}_{25-75}\right)$ & $90(81-100)$ & $95(88-104)$ & $90.5(84-98)$ & $78(68-90)$ & $74(60-81)$ & \\
\hline \multicolumn{6}{|l|}{ Feno (ppb) } & 0.873 \\
\hline Median $\left(\mid \mathrm{Q}_{25-75}\right)$ & $40(23-72)$ & $41(23-73)$ & $41(26-72)$ & $35.5(19-69)$ & $38(21-60)$ & \\
\hline \multicolumn{6}{|l|}{ Total lgE (IU/ml $)^{\S}$} & 0.0789 \\
\hline Median $\left(\mathrm{IQ}_{25-75}\right)$ & $255(117-563)$ & $225(111.5-533)$ & $274(113-615)$ & $305(124-711)$ & $213(93-426)$ & \\
\hline \multicolumn{6}{|c|}{ IgE Dermatophagoides pteronyssinus } & 0.0637 \\
\hline Median $\left(\mathrm{IQ}_{25-75}\right)$ & $42(15-100)$ & $34(13-99)$ & $51(21-101)$ & $44(16-100)$ & $42(5.8-98)$ & \\
\hline \multicolumn{6}{|c|}{ IgE Dermatophagoides farinae } & 0.119 \\
\hline Median $\left(\mathrm{IQ}_{25-75}\right)$ & $27(11-79)$ & $21(10-66)$ & $34(12-81)$ & $26(11-85)$ & $32(5.7-78.8)$ & \\
\hline \multicolumn{6}{|l|}{ IgE Blomia tropicalis } & 0.931 \\
\hline Median $\left(\mathrm{IQ}_{25-75}\right)$ & $7(2.1-21)$ & $7(2-19)$ & $6.8(3-23)$ & $8.8(2.1-20)$ & $6.9(3-19)$ & \\
\hline \multicolumn{6}{|l|}{ IgE Lepidoglyphus destructor } & 0.448 \\
\hline Median $\left(\mathrm{IQ}_{25-75}\right)$ & $2.4(1-7)$ & $2.6(0.9-6)$ & $2.1(1-6)$ & $2.1(1-11)$ & $4.1(2-9)$ & \\
\hline \multicolumn{6}{|l|}{ IgE Tyrophagus putrescientae } & 0.743 \\
\hline Median $\left(\mathrm{IQ}_{25-75}\right)$ & $2(1-7.5)$ & $3(1-7)$ & $2(1-7)$ & $2(1-8.5)$ & $3.1(1-1.9)$ & \\
\hline \multicolumn{6}{|l|}{ IgE Acarus siro } & 0.389 \\
\hline Median $\left(\mathrm{IQ}_{25-75}\right)$ & $2.6(1-7)$ & $2.7(0.9-7.5)$ & $2.4(1-7)$ & $5(1-9)$ & $1.3(0.7-1.8)$ & \\
\hline \multicolumn{6}{|l|}{$\lg A(m g / d L)^{\S}$} & $0.00024^{\ddagger}$ \\
\hline Median $\left(\mathrm{IQ}_{25-75}\right)$ & $217(162-279)$ & $220.5(164-292)$ & $205.5(157-260)$ & $205.5(161-271.5)$ & $268(220-334)$ & \\
\hline \multicolumn{6}{|l|}{ Eosinophils $\left(10^{9} / \mathrm{L}\right)^{\S}$} & 0.153 \\
\hline Median $\left(\mathrm{IQ}_{25-75}\right)$ & $0.3(0.2-0.5)$ & $0.3(0.2-0.5)$ & $0.3(0.2-0.5)$ & $0.3(0.2-0.5)$ & $0.3(0.1-0.5)$ & \\
\hline \multicolumn{6}{|l|}{ Nasal cytology eosinophils (\%) } & 0.265 \\
\hline Median $\left(\mathrm{IQ}_{25-75}\right)$ & $37.5(10-70)$ & $40(10-70)$ & $40(15-70)$ & $30(5-50)$ & $40(5-60)$ & \\
\hline \multicolumn{6}{|l|}{ AAT $(m g / d L)^{\S}$} & 0.945 \\
\hline Median $\left(\mathrm{IQ}_{25-75}\right)$ & $134(118-154)$ & $135(115-159)$ & $134(118-154)$ & $133(116-149)$ & $135(119-144)$ & \\
\hline
\end{tabular}

FEV1 (forced expiratory volume in the $1 \mathrm{~s}$ ), FENO (fractional exhaled nitric oxide), IgE (immunoglobulin E), IgA (immunoglobulin A), AAT (alpha1 antitrypsin)

* Kruskal-Wallis statistic analysis for continuous non normal variables and Chi square or F-test for nominal ones

* Statistical significance, $\mathrm{p}$ value $<0.01$

$\S$ Normal value lgE: 10-179 IU/ml; Normal value of IgA: 80-310 mg/dl; Normal value of blood eosinophils: 0-0.54 × 109/L; Normal value ATT: 100-200 mg/dL $(1.0-2.0 \mathrm{~g} / \mathrm{L})$ 
previous pneumonias or even frequent respiratory infections the year before entering the study. Respiratory function values and analytical determinations are also represented in Table 1.

Median blood eosinophil count was $0.3 \times 10^{9} / \mathrm{L}(0.2-$ 0.5). Median percentage of eosinophils found in the nasal cytology was $37.5 \%$ (10-70), with no significant differences among all stages of disease severity. The median serum IgE was high, $255 \mathrm{IU} / \mathrm{ml}(117-563)$ as compared to the normal value $(<100 \mathrm{IU} / \mathrm{ml})$, but there was no significant difference among asthma groups. The values of specific IgE were quite similar among all groups. IgA serum levels were significantly higher in patients with severe asthma $(268 \mathrm{mg} / \mathrm{dl}$ - normal value $80-310 \mathrm{mg} / \mathrm{dl})$ as compared to the other groups (moderate [205.5 mg/ $\mathrm{dl}]$, mild $[205.5 \mathrm{mg} / \mathrm{dl}]$ and intermittent $[220.5 \mathrm{mg} / \mathrm{dl}]$ ) $(\mathrm{p}=0.00024)$.

Median AAT value was $134 \mathrm{mg} / \mathrm{dl}$ (118-154), within normal range (100-200 $\mathrm{mg} / \mathrm{dL}$ ), and no significant difference was observed according to the severity of the disease. Sixty-six (10.2\%) asthmatics had serum AAT levels below the lower limit of normal $(<100 \mathrm{mg} / \mathrm{dl})$ and only three $(0.5 \%)$ had severe deficiency $(<57 \mathrm{mg} / \mathrm{dl})$ [24].

One hundred and forty-five patients (22.4\%) had a deficient AAT genotype. No individual with severe AAT deficiency genotype (PI*ZZ) was identified in our series.

Demographic and clinical characteristics according to PI genotype are shown in Table 2. The distribution of all different severity asthma stages among all AAT genotypes was similar, and no significant difference was observed. However, peripheral eosinophils were significantly lower in the PI*MS group $(\mathrm{p}=0.0228)$. As was expected, the serum levels of ATT were lower in PI"MZ and PI*SZ groups $\left(\mathrm{p}=1.18^{-25}\right)$. Analytical and functional respiratory test variables are illustrated in Table 3. Finally, we did not find any significant association between AATD and AAT genotypes and the risk of having severe persistent asthma (Table 4).

\section{Discussion}

Many authors have suggested an increased risk of asthma with some AAT genotypes. Eden et al. [16] showed that $44 \%$ of patients with AATD (20-25\% of them with an allergy) had asthma, which was three times more prevalent in PI*MZ subjects than in PI*ZZ individuals. Other investigators have found an even higher percentage of asthmatics among $\mathrm{PI}$ *SS population when compared to subjects without deficient alleles [25]. We have not found any clinical association between AATD and AAT genotypes and severity of asthma among HDM sensitized patients. Indeed, the distribution of deficient genotypes among all asthma severity categories was very similar to that described previously in Spanish asthmatic population (Table 5).

The balance between normal lung inflammation and repair is a complex process that involves pro- and antiinflammatory cytokines and the accumulation of inflammatory and immune effector cells [26]. In this work,

Table 2 Demographic and clinical characteristics according to alpha 1 antitrypsin genotypes

\begin{tabular}{|c|c|c|c|c|c|c|}
\hline & $P I * M M(n=503)$ & $P I * M S(n=110)$ & $P I^{*} M Z(n=15)$ & $P I * S S(n=14)$ & $P I^{*} S Z(n=6)$ & P value \\
\hline $\operatorname{Sex} n(\%)$ & & & & & & 0.525 \\
\hline Male & $178(35)$ & $35(32)$ & $3(20)$ & $6(43)$ & $1(17)$ & \\
\hline Female & $325(65)$ & $75(68)$ & $12(80)$ & $8(57)$ & $5(83)$ & \\
\hline Age, years & & & & & & 0.818 \\
\hline Median $\left(\mathrm{IQ}_{25-75}\right)$ & $28(20-38)$ & $31(23-38)$ & $30(24-38)$ & $32(20-36)$ & $20.5(19-36)$ & \\
\hline Smokers n (\%) & $37(7.4)$ & $11(10)$ & $4(26.7)$ & $2(14.3)$ & 0 & 0.0882 \\
\hline Intermittent asthma n (\%) & $191(38)$ & $45(41)$ & $4(26.7)$ & $9(64.3)$ & $4(66.7)$ & 0.134 \\
\hline Mild persistent asthma (\%) & 194 (38.6) & $39(35.5)$ & $6(40)$ & $5(35.7)$ & $2(33.3)$ & 0.981 \\
\hline Moderate persistent asthma n (\%) & $78(15.5)$ & $18(16.4)$ & $4(26.7)$ & 0 & 0 & 0.303 \\
\hline Severe persistent asthma n (\%) & $39(7.8)$ & $8(7.3)$ & $1(6.7)$ & 0 & 0 & 0.958 \\
\hline Polyposis n (\%) & $9(1.8)$ & $6(5.5)$ & $2(13.3)$ & 0 & 0 & 0.104 \\
\hline Chronic sinusitis n (\%) & $24(4.8)$ & $3(2.7)$ & $2(13.3)$ & $2(14.3)$ & $1(16.7)$ & 0.0516 \\
\hline Atopic dermatitis n (\%) & $17(3.4)$ & $4(3.6)$ & 0 & $1(7.1)$ & $1(16.7)$ & 0.271 \\
\hline Previous pneumonia n (\%) & $4(0.8)$ & $1(0.9)$ & 0 & 0 & 0 & 1 \\
\hline > 3infections/year n (\%) & $4(0.8)$ & 0 & 0 & 0 & 0 & 1 \\
\hline Previous treatment: oral glucocorticosteroids n (\%) & $10(2)$ & $2(1.8)$ & 0 & 0 & 0 & 1 \\
\hline Previous treatment: immunotherapy n (\%) & $38(7.6)$ & $10(9.1)$ & 0 & 0 & 0 & 0.804 \\
\hline Previous treatment: omalizumab n (\%) & $1(0.2)$ & 0 & 0 & 0 & 0 & 1 \\
\hline
\end{tabular}

* Kruskal-Wallis statistic analysis for continuous non normal variables and Chi square or F-test for nominal ones 
Table 3 Analytical and functional respiratory tests according to alpha 1 antitrypsin genotype

\begin{tabular}{|c|c|c|c|c|c|c|}
\hline & $\mathrm{PI} * \mathrm{MM}(\mathrm{n}=503)$ & $\mathrm{PI} * \mathrm{MS}(\mathrm{n}=110)$ & $P I^{*} M Z(n=15)$ & $\mathrm{PI}^{*} \mathrm{SS}(\mathrm{n}=14)$ & $\mathrm{PI}^{*} \mathrm{SZ}(\mathrm{n}=6)$ & P value* \\
\hline \multicolumn{6}{|l|}{ FEV1 (I) } & \multirow[t]{2}{*}{0.23} \\
\hline Median $\left(I Q_{25-75}\right)$ & $2.9(2.5-3.4)$ & $2.9(2.4-3.4)$ & $2.9(2.7-3.3)$ & $3.1(2.8-3.7)$ & $3.3(3.2-3.3)$ & \\
\hline \multicolumn{6}{|l|}{ FEV1 (\%) } & \multirow[t]{2}{*}{0.0763} \\
\hline Median $\left(\mathrm{IQ}_{25-75}\right)$ & $90(81-100)$ & $91(76-101)$ & $92(84-105)$ & $97(86-99)$ & $101(99-111)$ & \\
\hline \multicolumn{6}{|l|}{ Total lgE $(\mathrm{IU} / \mathrm{dL})^{\S}$} & \multirow[t]{2}{*}{0.194} \\
\hline Median $\left(\mathrm{IQ}_{25-75}\right)$ & $272(124-576)$ & $207(74-538)$ & $165(115-399)$ & $151(127-646)$ & $169(90-582)$ & \\
\hline \multicolumn{6}{|c|}{ IgE Dermatophagoides pteronyssinus } & \multirow[t]{2}{*}{0.372} \\
\hline Median $\left(\mathrm{IQ}_{25-75}\right)$ & $45(17-100)$ & $31(9-101)$ & $70(11-101)$ & $34(20-89)$ & $61(30-101)$ & \\
\hline \multicolumn{6}{|c|}{ IgE Dermatophagoides farinae } & \multirow[t]{2}{*}{0.273} \\
\hline Median $\left(\mathrm{IQ}_{25-75}\right)$ & $29(12-80)$ & $17(6.6-54)$ & $41(14-79)$ & $24(8.8-74)$ & $31(21-84)$ & \\
\hline \multicolumn{6}{|l|}{ IgE Blomia tropicalis } & \multirow[t]{2}{*}{0.89} \\
\hline Median $\left(\mathrm{IQ}_{25-75}\right)$ & $7(2.1-22)$ & $8(2.5-19)$ & $6(5.2-9.6)$ & $9.5(2-18)$ & $4.5(1-8.5)$ & \\
\hline \multicolumn{6}{|c|}{ IgE Lepidoglyphus destructor } & \multirow[t]{2}{*}{0.348} \\
\hline Median $\left(\mathrm{IQ}_{25-75}\right)$ & $2(1-6)$ & $3.1(1.1-8)$ & $4(3.6-10)$ & $4(2-8)$ & $2.2(2-16)$ & \\
\hline \multicolumn{6}{|c|}{ IgETyrophagus putrescientae } & \multirow[t]{2}{*}{0.409} \\
\hline Median $\left(\mathrm{IQ}_{25-75}\right)$ & $2.3(1-8)$ & $2.3(1.4-5)$ & $1(1-1.01)$ & $1.6(0.7-8)$ & 2.1 & \\
\hline \multicolumn{6}{|l|}{ IgE Acarus siro } & \multirow[t]{2}{*}{0.129} \\
\hline Median $\left(\mathrm{IQ}_{25-75}\right)$ & $2(0.9-7)$ & $4(3-5)$ & $10(4.3-35)$ & $5.5(1-11)$ & 23.3 & \\
\hline \multicolumn{6}{|l|}{$\lg \mathrm{A}(\mathrm{mg} / \mathrm{dL})^{5}$} & \multirow[t]{2}{*}{0.333} \\
\hline Median $\left(\mathrm{IQ}_{25-75}\right)$ & $216.5(164-285)$ & $204(150.8-261)$ & $261(181-331)$ & $224(193-238)$ & $255(160-267)$ & \\
\hline \multicolumn{6}{|l|}{ Eosinophils $\left(10^{9} / \mathrm{L}\right)^{\S}$} & \multirow[t]{2}{*}{$0.0228^{\ddagger}$} \\
\hline Median $\left(\mathrm{IQ}_{25-75}\right)$ & $0.3(0.2-0.5)$ & $0.3(0.2-0.4)$ & $0.4(0.3-0.6)$ & $0.5(0.3-0.6)$ & $0.3(0.2-0.4)$ & \\
\hline \multicolumn{6}{|c|}{ Nasal cytology eosinophils (\%) } & \multirow[t]{2}{*}{0.378} \\
\hline Median $\left(\mathrm{IQ}_{25-75}\right)$ & $40(10-70)$ & $20(7.5-60)$ & $45(33-65)$ & $50(30-65)$ & 50 & \\
\hline \multicolumn{6}{|l|}{ AAT $(m g / d L)^{\S}$} & \multirow[t]{2}{*}{$1.18 \mathrm{e}-25^{\ddagger}$} \\
\hline Median $\left(\mathrm{IQ}_{25-75}\right)$ & $138(123-159)$ & $116(104-137)$ & $80(78-87)$ & $89(86-96)$ & $64(61.3-70.5)$ & \\
\hline
\end{tabular}

FEV1 (forced expiratory volume in the $1 \mathrm{~s}$ ), IgE (immunoglobulin E), IgA (immunoglobulin A), AAT (alpha1 antitrypsin)

* Kruskal-Wallis statistic analysis

* Statistical significance, $\mathrm{p}$ value $<0.05$

$\S$ Normal value IgE: 10-179 IU/ml; Normal value of IgA: 80-310 mg/dl; Normal value of blood eosinophils: 0-0.54 × 109/L; Normal value ATT: 100-200 mg/dL $(1.0-2.0 \mathrm{~g} / \mathrm{L})$

Table 4 Relationship between AATD or AAT genotypes and severe persistent asthma

\begin{tabular}{|c|c|c|c|}
\hline & $\begin{array}{l}\text { Severe persistent } \\
\text { asthma OR }(95 \% \mathrm{CI})\end{array}$ & P value* & $\begin{array}{l}\text { Multivariable } \\
\text { correction** }^{* *}\end{array}$ \\
\hline $\mathrm{Pl}{ }^{*} \mathrm{MM}$ & $1.2700(0.6-2.69)$ & 0.532 & 0.382 \\
\hline $\mathrm{PI}{ }^{*} \mathrm{MS}$ & $0.9760(0.44-2.15)$ & 0.953 & 0.665 \\
\hline $\mathrm{PI} * \mathrm{SS}$ & 0.00000078 (0-Inf) & 0.983 & 0.992 \\
\hline$P I^{*} M Z$ & $0.8910(0.12-6.92)$ & 0.912 & 0.953 \\
\hline $\mathrm{Pl}^{*} \mathrm{SZ}$ & $0.000000791(0-\operatorname{lnf})$ & 0.989 & 0.995 \\
\hline SAATD & $6.3600(0.57-71.5)$ & 0.134 & 0.711 \\
\hline AATD & $0.5680(0.17-1.88)$ & 0.355 & 0.992 \\
\hline
\end{tabular}

PI: protease inhibitor, SAATD (severe alpha 1 antitrypsin deficiency, $<57 \mathrm{mg} / \mathrm{dl}$ ), AATD (alpha1 antitrypsin deficit, $<100 \mathrm{mg} / \mathrm{dl}$ )

* Binary logistic regression

** Adjusted for age, conjunctivitis, polyposis, ex-smokers, passive smokers contrary to previous investigations, we studied a specific group of asthmatic patients sensitized to HDM. It has been proved that mites produce a huge inflammatory reaction in the lung, not only through $\mathrm{CD} 4+\mathrm{Th} 2$ cells that induce an IgE allergic response, but also through the innate immune system [27]. Different researchers have provided ample evidence that some components of $D$ pteronyssinus, such as group 1 allergens (Der $\mathrm{p} 1$ ), can activate different routes that alter the immune system [28]. Other allergens, such as Der p 3 and Der p 6, also seem to contribute to the HDM allergic response [29]. It is even more intriguing how these allergens can also directly damage the respiratory epithelium by activating mast cell independent of IgE [30].

ATT inhibits neutrophil serine proteases and can regulate the chemotaxis of neutrophils in two different ways: 
Table 5 Protease inhibitor genotype distribution in different populations

\begin{tabular}{llllll}
\hline & PI*MM & PI*MS & PI*MZ & PI*SS & PI*SZ \\
\hline Our population $(n=648)$ & $503(77.62 \%)$ & $110(16.98 \%)$ & $15(2.31 \%)$ & $14(2.16 \%)$ & $6(0.93 \%)$ \\
Spanish population [7] & - & $1 / 5(20 \%)$ & $1 / 33(3 \%)$ & $1 / 92(1.1 \%)$ & $1 / 278(0.36 \%)$ \\
Miravitles et al. study [37] & $333(75.7 \%)$ & $84(19.1 \%)$ & $14(3.2 \%)$ & - & 0 \\
\hline
\end{tabular}

PI (protease inhibitor)

inhibition of IL8-CXCR1 interaction and modulation of ADAM17 activity impeding Fc $\gamma$ RIIIb release [31]. The inactivation of ATT by some major components of $D$ pteronyssinus, such as Der $\mathrm{p} 1$, has already been proven [32]. The majority of our patients $(96.5 \%)$ were sensitized to this mite and consequently, the anti-inflammatory action of ATT can be missing in this population. Thus, it is conceivable to think that there could be a possible association between AATD and severity of allergic asthma. However, we have not been able to find a significant association between AATD and severe asthma, as it was reported previously by van Veen et al. in asthmatic patients without a known sensitivity [33]. Neither total IgE nor HDM specific IgE were higher in the most severe asthmatic cases [34]. What we observed is higher serum levels of IgA in patients with severe asthma, as has already been reported [35]. That is why we included serum IgA in the multivariate analysis.

We have also assessed the distribution of different AAT genotypes in our series, which does not differ from the general population in our country $[7,36]$. Furthermore, asthmatic carriers of deficient genotypes did not have different clinical expression of asthma, as it was reported before in a non-selected population of asthmatic patients [37] and in a population with severe asthma [33]. AAT serum levels were lower in asthmatic carriers of $\mathrm{Z}$ allele $[38,39]$, but there was no correlation of functional respiratory values neither with serum AAT levels nor AAT genotypes. These results are similar to those reported by others $[33,40]$. Nevertheless, another study, conducted with children, suggested that, although low levels of AAT do not enhance the risk of developing asthma, an impaired AAT balance may potentially increase the vulnerability for decrease in lung function and bronchial hyperreactivity in asthmatic children [41].

In contrast to previous reports [37], we have found lower levels of blood eosinophils in PI*MS subjects in comparison to other genotypes. Likewise, the percentage of eosinophils in nasal cytology was also lower in the PI*MS group, though not significantly.

We recognize that our study has some limitations. First of all, we did not predict the required sample size by power calculation, but we strongly believe that this sample of patients truly reflects what happens to the asthmatic population. Moreover, our series is the largest sample studied at the moment. Secondly, we could not find any patient heterozygous for $\mathrm{Z}$ allele but this genotype is extremely uncommon and less prevalent in Spain. Finally, we only measured serum ATT levels and we do not know if the local production of ATT by pulmonary epithelial cells and macrophages may balance the low serum ATT levels.

To conclude, we could not find any association between AATD and asthma severity among patients sensitized to HDM. Our findings support what has been reported by others in smaller series of asthmatics. The proportion of asthmatics with deficient AAT genotypes in our series is similar to the proportion in the general population. Although the blood count and nasal eosinophils values seem to be different among the different genotypes, more studies are needed to confirm this due to the scarcity of asthmatic allergic populations with alleles $\mathrm{PI} Z \mathrm{Z}$.

\section{Abbreviations}

ATT: alpha1 antitrypsin; ATTD: alpha 1 antitrypsin deficiency; COPD: chronic obstructive pulmonary disease; FeNO: fractional exhaled nitric oxide; FEV1: forced expiratory volume in $1 \mathrm{~s}$; FVC: forced vital capacity; HDM: house dust mites; ICS: inhalated glucocorticosteroids; IgA: immunoglobulin A; IgE: immunoglobulin E; LABA: long-acting $\beta 2$-agonists; PI: protease inhibitor; SABA: short-acting $\beta 2$-agonists; SATTD: severe alpha 1 antitrypsin deficiency.

\section{Authors' contributions}

ISL, FRC, DCN, EHR, CRG, TCD: Conceived ideas or/and experiment design. ISL, DCN, TCD: Data collection. ISL: Data analysis. ISL, FRC, CRG, TCD: Interpretation of results. ISL, FRC, DCN, EHR, CRG, TCD: Revision of the content. All authors read and approved the final manuscript.

\section{Author details}

${ }^{1}$ Postgraduate and Doctoral School, Universidad de Las Palmas de Gran Canaria, Camino Real de San Roque, 1, 35015 Las Palmas de Gran Canaria, Las Palmas, Spain. ${ }^{2}$ Pneumology Unit, Hospital Universitario de Gran Canaria Doctor Negrín, Las Palmas de Gran Canaria, Spain. ${ }^{3}$ Allergy Unit, Hospital General de Fuerteventura, Puerto del Rosario, Spain. ${ }^{4}$ Immunology Unit, Hospital Universitario de Gran Canaria Doctor Negrín, Las Palmas de Gran Canaria, Spain. ${ }^{5}$ Allergy Unit, Hospital Universitario de Gran Canaria Doctor Negrín, Las Palmas de Gran Canaria, Spain.

\section{Acknowledgements}

The authors are very grateful to ALK-Abelló for the financial support.

\section{Competing interests}

The authors declare that they have no competing interests. 


\section{Availability of data and materials \\ Not applicable.}

\section{Consent for publication}

Written informed consent was obtained from all subjects before participating in the study.

\section{Ethics approval and consent to participate}

The study was approved by the Ethics Committee of the hospital.

\section{Funding}

Instituto de Salud Carlos III. Award number PI12/01565 (Recipient Carlos Rodriguez-Gallego). Instituto de Salud Carlos III. Award number PI10/01718 (Recipient Carlos Rodriguez-Gallego)

\section{Publisher's Note}

Springer Nature remains neutral with regard to jurisdictional claims in published maps and institutional affiliations.

\section{Received: 13 July 2018 Accepted: 27 September 2018}

Published online: 02 November 2018

\section{References}

1. Cosio MG, Bazzan E, Rigobello C, Tinè M, Turato G, Baraldo S, et al. Alpha-1 antitrypsin deficiency: beyond the protease/antiprotease paradigm. Ann Am Thorac Soc. 2016;13(Suppl 4):S305-10.

2. McCarthy C, Reeves EP, McElvaney NG. The role of neutrophils in alphaantitrypsin deficiency. Ann Am Thorac Soc. 2016;13(Suppl 4):S297-304.

3. Laurell C-B, Eriksson S. The electrophoretic a1-globulin pattern of serum in a1-antitrypsin deficiency 1963. COPD. 2013;10(Suppl 1):3-8.

4. Dickens JA, Lomas DA. Why has it been so difficult to prove the efficacy of alpha-1-antitrypsin replacement therapy? Insights from the study of disease pathogenesis. Drug Des Devel Ther. 2011:5:391-405.

5. de Serres FJ, Blanco I. Prevalence of a1-antitrypsin deficiency alleles PI*S and $\mathrm{PI}^{*} \mathrm{Z}$ worldwide and effective screening for each of the five phenotypic classes $\mathrm{PI}{ }^{*} \mathrm{MS}, \mathrm{PI}{ }^{*} \mathrm{MZ}, \mathrm{PI}{ }^{*} \mathrm{SS}, \mathrm{PI}{ }^{*} \mathrm{SZ}$, and $\mathrm{PI}{ }^{*} \mathrm{ZZ}$ : a comprehensive review. Ther Adv Respir Dis. 2012;6(5):277-95.

6. Stockley RA, Dirksen A, Stolk J. Alpha-1 antitrypsin deficiency: the European experience. COPD. 2013;10(Suppl 1):50-3.

7. Blanco I, de Serres FJ, Fernandez-Bustillo E, Lara B, Miravitlles M. Estimated numbers and prevalence of $\mathrm{PI}^{*} \mathrm{~S}$ and $\mathrm{PI}^{*} \mathrm{Z}$ alleles of alpha1-antitrypsin deficiency in European countries. Eur Respir J. 2006:27(1):77-84.

8. Lara B, Blanco I, Martínez MT, Rodríguez E, Bustamante A, Casas F, et al. Spanish registry of patients with alpha-1 antitrypsin deficiency: database evaluation and population analysis. Arch Bronconeumol. 2017;53(1):13-8.

9. Lara B, Miravitlles M. Spanish registry of patients with alpha-1 antitrypsin deficiency; comparison of the characteristics of PISZ and PIZZ individuals. COPD. 2015;12(Suppl 1):27-31.

10. Sørheim I-C, Bakke P, Gulsvik A, Pillai SG, Johannessen A, Gaarder PI, et al. $a_{1}$-Antitrypsin protease inhibitor $M Z$ heterozygosity is associated with airflow obstruction in two large cohorts. Chest. 2010;138(5):1125-32.

11. Dahl M, Hersh CP, Ly NP, Berkey CS, Silverman EK, Nordestgaard BG. The protease inhibitor PI*S allele and COPD: a meta-analysis. Eur Respir J. 2005;26(1):67-76.

12. Hersh CP, Dahl M, Ly NP, Berkey CS, Nordestgaard BG, Silverman EK. Chronic obstructive pulmonary disease in alpha1-antitrypsin PI MZ heterozygotes: a meta-analysis. Thorax. 2004;59(10):843-9.

13. Mehta AJ, Thun GA, Imboden M, Ferrarotti I, Keidel D, Künzli N, et al. Interactions between SERPINA1 PiMZ genotype, occupational exposure and lung function decline. Occup Environ Med. 2014;71(4):234-40.

14. Siri $D$, Farah $H$, Hogarth DK. Distinguishing alpha1-antitrypsin deficiency from asthma. Ann Allergy Asthma Immunol. 2013;111(6):458-64.

15. Strange $C$. Airway disease in alpha-1 antitrypsin deficiency. COPD. 2013;10(Suppl 1):68-73.

16. Eden E, Strange C, Holladay B, Xie L. Asthma and allergy in alpha-1 antitrypsin deficiency. Respir Med. 2006:100(8):1384-91.

17. American Thoracic Society, European Respiratory Society. American Thoracic Society/European Respiratory Society statement: standards for the diagnosis and management of individuals with alpha-1 antitrypsin deficiency. Am J Respir Crit Care Med. 2003;168(7):818-900.

18. Alpha 1-antitrypsin deficiency: memorandum from a WHO meeting. Bull World Health Organ. 1997;75(5):397-415.

19. GEMA 4.0 [Internet]. Gemasma. [cited 2017 Oct 26]. https://www.gemas ma.com/.

20. Bousquet J, Heinzerling L, Bachert C, Papadopoulos NG, Bousquet PJ, Burney $P G$, et al. Practical guide to skin prick tests in allergy to aeroallergens. Allergy. 2012:67(1):18-24.

21. Ahsen N von, Oellerich M, Schütz E. Use of two reporter dyes without interference in a single-tube rapid-cycle PCR: a1-antitrypsin genotyping by multiplex real-time fluorescence PCR with the lightcycler. Clinical Chemistry [Internet]. 2000 Feb 1 [cited 2018 Apr 12];46(2):156-61. http:// clinchem.aaccjnls.org/content/46/2/156.

22. R Core Team. R: A language and environment for statistical computing. [Internet]. Vienna, Austria.: R Foundation for Statistical Computing, 2017. https://www.R-project.org/.

23. Mincheva R, Ekerljung L, Bossios A, Lundbäck B, Lötvall J. High prevalence of severe asthma in a large random population study. J Allergy Clin Immunol. 2018;141(6):2256-64.

24. Stoller JK, Lacbawan FL, Aboussouan LS. Alpha-1 Antitrypsin deficiency. In: Adam MP, Ardinger HH, Pagon RA, Wallace SE, Bean LJ, Mefford HC, et al. editors. GeneReviews $\left({ }^{\circledR}\right)$ [Internet]. Seattle (WA): University of Washington, Seattle; 1993 [cited 2017 Oct 24]. http://www.ncbi.nlm.nih.gov/ books/NBK1519/.

25. McGee D, Schwarz L, McClure R, Peterka L, Rouhani F, Brantly M, et al. Is PiSS alpha-1 antitrypsin deficiency associated with disease? Pulm Med. 2010;2010:570679.

26. Stockley RA. The multiple facets of alpha-1-antitrypsin. Ann Transl Med. 2015;3(10):130.

27. Calderón MA, Linneberg A, Kleine-Tebbe J, De Blay F, de Rojas DHF, Virchow JC, et al. Respiratory allergy caused by house dust mites: What do we really know? J Allergy Clin Immunol. 2015;136(1):38-48.

28. Bouchecareilh $M$, Balch WE. Proteostasis, an emerging therapeutic paradigm for managing inflammatory airway stress disease. Curr Mol Med. 2012:12(7):815-26.

29. Jacquet A, Campisi V, Szpakowska M, Dumez M-E, Galleni M, Chevigné A. Profiling the extended cleavage specificity of the house dust mite protease allergens Der $p$ 1, Der $p 3$ and Der $p 6$ for the prediction of new cell surface protein substrates. Int J Mol Sci. 2017;18(7):1373.

30. Takai T, Ikeda S. Barrier dysfunction caused by environmental proteases in the pathogenesis of allergic diseases. Allergol Int. 2011:60(1):25-35.

31. Bergin DA, Reeves EP, Meleady P, Henry M, McElvaney OJ, Carroll TP, et al. a-1 Antitrypsin regulates human neutrophil chemotaxis induced by soluble immune complexes and IL-8. J Clin Invest. 2010;120(12):4236-50.

32. Kalsheker NA, Deam S, Chambers L, Sreedharan S, Brocklehurst K, Lomas $D A$. The house dust mite allergen Der p1 catalytically inactivates alpha 1 -antitrypsin by specific reactive centre loop cleavage: a mechanism that promotes airway inflammation and asthma. Biochem Biophys Res Commun. 1996;221(1):59-61.

33. van Veen $I H$, ten Brinke $A$, van der Linden AC, Rabe KF, Bel EH. Deficient alpha-1-antitrypsin phenotypes and persistent airflow limitation in severe asthma. Respir Med. 2006:100(9):1534-9.

34. Davila I, Valero A, Entrenas LM, Valveny N, Herráez L, SIGE Study Group. Relationship between serum total lgE and disease severity in patients with allergic asthma in Spain. J Investig Allergol Clin Immunol. 2015:25(2):120-7

35. Kim W-J, Choi IS, Kim CS, Lee J-H, Kang H-W. Relationship between serum IgA level and allergy/asthma. Korean J Intern Med. 2017;32(1):137-45

36. Blanco I, Fernández-Bustillo E, de Serres FJ, Alkassam D, Rodríguez Menéndez C. PI*S and $\mathrm{P}{ }^{*} Z$ alpha 1-antitrypsin deficiency: estimated prevalence and number of deficient subjects in Spain. Med Clin (Barc). 2004;123(20):761-5

37. Miravitlles M, Vilà S, Torrella M, Balcells E, Rodríguez-Frías F, de la Roza C, et al. Influence of deficient alpha1-anti-trypsin phenotypes on clinical characteristics and severity of asthma in adults. Respir Med. 2002;96(3):186-92.

38. Ferrarotti I, Thun GA, Zorzetto M, Ottaviani S, Imboden M, Schindler C, et al. Serum levels and genotype distribution of a1-antitrypsin in the general population. Thorax. 2012;67(8):669-74. 
39. Zorzetto M, Russi E, Senn O, Imboden M, Ferrarotti I, Tinelli C, et al. SERPINA1 gene variants in individuals from the general population with reduced alpha1-antitrypsin concentrations. Clin Chem. 2008;54(8):1331-8.

40. Silva GE, Sherrill DL, Guerra S, Barbee RA. A longitudinal study of alpha1antitrypsin phenotypes and decline in FEV1 in a community population. Chest. 2003;123(5):1435-40
41. von Ehrenstein OS, Maier EM, Weiland SK, Carr D, Hirsch T, Nicolai T, et al. Alpha1 antitrypsin and the prevalence and severity of asthma. Arch Dis Child. 2004:89(3):230-1.
Ready to submit your research? Choose BMC and benefit from:

- fast, convenient online submission

- thorough peer review by experienced researchers in your field

- rapid publication on acceptance

- support for research data, including large and complex data types

- gold Open Access which fosters wider collaboration and increased citations

- maximum visibility for your research: over $100 \mathrm{M}$ website views per year

At BMC, research is always in progress.

Learn more biomedcentral.com/submissions 